\title{
Hemşirelerin Yaşam Doyumu ve Umutsuzluk Düzeyleri Arasındaki İlişki
}

\section{The Relationship Between of Life Satisfaction and Hopelessness Levels of Nurses}

\author{
${ }^{1}$ İbrahim TOPUZ
}

${ }^{1}$ Amasya Üniversitesi, Sağlık Bilimleri Fakültesi, Hemşirelik Bölümü, Amasya, Türkiye

İbrahim Topuz: https://orcid.org/0000-0003-0540-2095

\section{ÖZ}

Amaç: Hemşirelerin yaşam doyumu ve umutsuzluk düzeyleri arasındaki ilişkiyi belirlemektir.

Materyal ve Metot: Tanımlayıcı türdeki çalışma bir eğitim ve araştırma hastanesinde 2018 yılı itibariyle çalışan hemşirelerle yürütülmüştür. Veriler Haziran-Eylül 2018 tarihlerinde Kişisel Bilgi Formu, Beck Umutsuzluk Ölçeği (BUÖ) ve Yaşam Doyumu Ölçeği (YDÖ) kullanılarak toplanmıştır. Araştırma verilerinin analizinde SPSS paket programı kullanılmıştır.

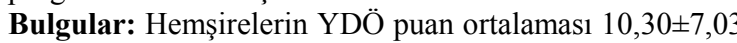
ve BUÖ puan ortalaması $6,06 \pm 4,63$ olarak belirlenmiştir. Yüksek eğitim seviyesi ile gündüz mesaisinde çalışanların, yaşam doyumlarının yükseldiği saptanmıştır $(\mathrm{p}<0,05)$. Kişiler arası ilişkilerini orta ve kötü düzeyde algılayanlarla çalışma yılı 11-15 olanların BUÖ puanları daha yüksektir $(\mathrm{p}<0,05)$. Yoğun seviyede umutsuzluk yaşayan hemşirelerde $(\% 61,5)$, YDÖ puanları daha yüksektir $(\mathrm{p}<0,05)$.

Sonuç: $\mathrm{Bu}$ çalışmada hemşireler orta düzeyde bir yaşam doyumunda ve hafif düzeyde umutsuzdur. Yoğun düzeyde umutsuzluk yaşayan hemşirelerin yüksek düzeyde yaşam doyumuna sahip olması, sosyal aktivitelerin yoğunluğu, kendine daha çok vakit ayırabilme durumlarıyla açıklanabilir.

Anahtar Kelimeler: Hemşire, umutsuzluk, yaşam doyu$\mathrm{mu}$

\section{ABSTRACT}

Objective: To determine the relationship between life satisfaction and hopelessness levels of nurses.

Materials and Methods: This descriptive study was conducted with nurses working at a training and research hospital in 2018. Data were collected between June and September 2018 using a Personal Information Form, Beck Hopelessness Scale (BHS) and Life Satisfaction Scale (LSS). SPSS package program was used in the analysis of the research data.

Results: The score average of the nurses LSS was 10,30 \pm 7,03 , BHS average score of $6.06 \pm 4.63$ was determined. It was found that the higher the education level and working during the daytime, increase life satisfaction $(p<0.05)$. The BHS scores of those who have a higher, poor and moderate perception of interpersonal relationships with 11-15 years of working $(p<0.05)$. Also, the intense hopeless nurses $(61.5 \%)$ had higher LSS scores $(\mathrm{p}<0.05)$.

Conclusion: Nurses had a moderate level of life satisfaction and slightly hopeness. The high level of life satisfaction of the nurses who intense hopeness, the intensity of social activities, the ability to devote more time to themselves can be explaned.

Keywords: Hopelessness, life satisfaction, nurse
Sorumlu Yazar / Corresponding Author:

İbrahim Topuz

Amasya Üniversitesi, Sağlık Bilimleri Fakültesi

İpekköy/AMASYA

Tel: +90358-218-17-67/ +90545-664-76-62

Fax: 0(358)-218-47-60

E-mail: ibrahimtopuz_38gs@hotmail.com
Yayın Bilgisi / Article Info:

Gönderi Tarihi/ Received: 12/09/2020

Kabul Tarihi/ Accepted: 19/10/2021

Online Yayın Tarihi/ Published: 01/12/2021

Atıf / Cited: Topuz İ. Hemşirelerin Yaşam Doyumu ve Umutsuzluk Düzeyleri Arasındaki İlişki. Online Türk Sağlık Bilimleri Dergisi 2021;6(4):472-481. doi:10.26453/otjhs.794138

\section{GíRiș}

Yaşam doyumu; bireylerin sahip oldukları ile beklentilerinin karşılaştırılmasıyla meydana gelen sonuç olarak tanımlanabilir. ${ }^{1-2}$ Kişilerin yaşamı algılamalarını da kapsayan yaşam doyumu kavramı, hemşirelik mesleğinde önemini korumaktadır. ${ }^{3}$ Hemşirelik tanıs1 olarak 1986 yilında kabul edilen ve Kuzey Ameri- ka Hemşirelik Tanıları Birliği (North American Nursing Diagnosis Association-NANDA) tarafindan tanımı yapılan umutsuzluk kavramı "bireylerin sınır1, hiç imkan bulamadığı ya da kişisel seçenekler sağlayamadığ diği bir durum olarak belirtilmektedir. ${ }^{4}$ 
Geleceğe yönelik olarak pozitif bakış açısına sahip olma hissini ifade eden umut ise, bireye karşılaşabileceği negatif yaşantılarla baş edebileceği hissini vererek ruh sağlığını pozitif yönde etkiliyorken, ${ }^{5}$ umutsuzluk ise bireylerin kendisinin veya bir başkasının geleceğine ilişkin olumsuz inanç ve beklentilerinden hareketle, ruh sağlığını negatif yönde etkilemektedir. ${ }^{6}$

Yaşam doyumunu etkileyen en önemli etmenlerden biri iş tatmini'dir. İş tatmininin yaşam doyumu üzerindeki etkisi, yaşam doyumunun iş tatmini üzerindeki etkisinden daha fazladır. ${ }^{7}$ Hemşirelik mesleğinin, vardiya sistemi, çalışma şartları, ücretleri, fiziksel ortamları, yoğun çalışma biçimi, mesleki riskler, rolleri ile iş tanımındaki belirsizlikler, çalışmaların takdir edilmemesi, mesleğin toplumsal imajının iyi olmaması ile adaletsizlik kapsamında problemleri yer almaktadır. Hemşirelerin mesleklerini icra ederken yaşamış oldukları bu problemler, yaşam doyumlarının düşmesine neden olmaktadır. ${ }^{3}$

Yapılan bazı çalışmalarda hemşirelerin ortalama seviyede bir yaşam doyumuna sahip olduğu belirtilirken, ${ }^{8,9}$ bazı çalışmalarda yüksek düzeyde bir yaşam doyumuna sahip oldukları bildirilmiştir. ${ }^{10}$ Ayrıca hemşirelerin yaşam doyumlarını etkileyen faktörlerin yaş, ${ }^{3,9,11}$ cinsiyet, ${ }^{12}$ medeni durum, ${ }^{3,8,12}$ gelir düzeyi algısı, ${ }^{8}$ eğitim düzeyi, ${ }^{13}$ çalışma yıll, ${ }^{3}$ kronik hastalık, sağlık düzeyini iyi algılama ve iş dışında hobi edinme durumu olduğu bildirilmiştir. ${ }^{8}$ Şili'de 2016 yılında palyatif bakım merkezi ve evde bakım merkezinde çalışan 64 hemşireyle gerçekleştirilmiş bir çalışmada; hemşirelerde empati duygusu ile yaşam doyumu arasında olumlu bir ilişki olduğu saptanmış, tükenmişlik durumlarının önlenerek, empati duygusunun geliştirilmesinin yaşam doyumunu yükseltebileceği vurgulanmıştır. ${ }^{14}$ Hemşirelerin yaşam doyumlarının düşük olması ve umutsuzluk düzeylerinin yükselmesi, hasta bireylere vermiş oldukları bakımın kalitesine önemli ölçüde yansımaktadır. Azalan bakım kalitesi bireylerin hastanede kalış süresini artırarak, iyileşme sürecinin uzamasına neden olacaktır. Dünyada sağlık hizmetlerinin en temel amacı, kanıt ve kılavuzlar rehberliğinde bilimsel temellere dayalı en iyi kalitede bakım sunulmasıdır. $\mathrm{Bu}$ hedef göz önüne alındığında hemşirelerin yaşam doyumu ile umutsuzluk düzeylerinin ne derecede önemli olduğu ortaya çıkmaktadır. ${ }^{15}$ Literatürde hemşirelerin yaşam doyumu ve umutsuzluk düzeyi arasındaki ilişkiyi inceleyen bir araştırmaya rastlanmamıştır. Bu çalışmada hemşirelerin yaşam doyumu ve umutsuzluk düzeyleri arasındaki ilişkinin incelenmesi amaçlanmıştır.

\section{MATERYAL VE METOT}

Araştırmanın Etik Yönü: Araştırmanın yapılması için bir devlet üniversitesinin girişimsel olmayan klinik araştırmalar etik kurulundan etik kurul izni (Tarih: 22.06.2018, karar no: E.15363) ve araştırmanın yürütüldüğü şehrin sağlık müdürlüğünden gerekli kurum izni (Tarih: 08.06.2018, karar no: 91734550-044) alınmıştır. Bu araştırmada Helsinki Deklarasyonu Prensipleri'ne uygun davranılmıştır. Hemşirelerden araştırmaya katılmaya gönüllü olduklarına yönelik yazılı onam alınmıştır.

Araştırmanın Tipi, Evren ve Örneklem: Tanımlayıc1 türde olan araştırmanın evrenini bir eğitim ve araştırma hastanesinde 2018 yılı itibariyle çalışan 321 hemşire oluşturmuştur. Araştırmada evrenin tamamına ulaşabilme hedeflendiği için örneklem seçimine gidilmeyerek, araştırma verilerinin toplandığı tarihte izinli olmayan, araştırmanın yürütüldüğü hastanede aktif çalışan, araştırmaya katılmaya gönüllü 123 hemşire araştırmanın örneklemini oluşturmuştur. $\mathrm{Bu}$ araştırma bir eğitim ve araştırma hastanesinde, Haziran-Eylül 2018 tarihleri arasında tamamlanmıştır.

Veri Toplama Araçları: Veriler kişisel bilgi formu, Yaşam Doyumu Ölçeği ve Beck Umutsuzluk Ölçeği kullanılarak toplanmıştır.

Kişisel Bilgi Formu: Hemşirelerin sosyo-demografik ve çalışma özelliklerini sorgulayan 12 sorudan oluşmaktadır.

Yaşam Doyumu Ölçeği (YDÖ): Diener, Emmons, Larsen ve Griffin ${ }^{16}$ tarafından geliştirilmiş, Dağlı ve Baysal $^{17}$ tarafından Türkçeye uyarlanıp geçerlikgüvenirlik çalışması yapılmıştır. Ölçek orijinalinde beşli likert tipi ve tek boyutludur. Geçerlilikgüvenirlilik çalışması sonucunda da yine benzer şekilde toplam beş maddeden, tek boyutlu ve beşli likert tipi şeklinde oluşturulmuştur. Ölçeğin Cronbach alfa iç tutarlık katsayısı 0,70-0,93 arasında değişmektedir. ${ }^{16} \mathrm{Bu}$ araştırmada ölçeğin cronbach alfa katsayısı 0,70 olarak belirlenmiştir. Ölçek "hiç katılmıyorum" ile "tamamen katıliyorum" arasında değişen 5 farklı puanlama sisteminden oluşmaktadır. Ölçeğin en düşük puanı 5 en yüksek puanı ise 35 'dir. YDÖ puanlamasında; 7 ve altında puan alma düşük doyum düzeyi, 8-12 arası puan alma orta yaşam doyumu düzeyi, 13 ve üzerinde puan alma yüksek yaşam doyumu düzeyi olarak kabul edilir. ${ }^{18}$ 
Beck Umutsuzluk Ölçeği (BUÖ): Beck ve arkadaşları $^{19}$ tarafından oluşturulan, Seber ${ }^{20}$ tarafından Türkçe geçerlik ve güvenirliği yapılan ölçek kullanılmıştır. Ölçek 20 sorudan meydana gelmektedir ve her sorudan 0-1 arası puan alınmaktadır. Soruların 11 tanesinde $(2,4,7,9,11,12,14,16,17,18$, 20) evet seçeneğinden, 9 tanesinde $(1,3,5,6,8,10$, $13,15,19)$ ise hayır seçeneğinden 1 puan alınmaktadır. Böylelikle ölçekten toplamda 0-20 puan arası bir puan alınmaktadır. Alınan puan yüksek ise bireydeki umutsuzluk düzeyinin yüksek olduğu düşünülmektedir. Ayrica bu puan; 0-3 arasinda ise normal, 4-8 puan arasında ise hafif, 9-14 arasında ise orta, 15 ve üzerinde ise yoğun düzeyde umutsuzluk söz konusudur. BUÖ, "gelecek ile ilgili duygular ve beklentiler" $(1,3,7,11,18)$, "motivasyon kaybı" $(2,4,9$, $12,14,16,17,20)$ ve "umut" $(5,6,8,10,13,15,19)$ olarak üç alt boyuta ayrılmaktadır. Ölçeğin Cronbach alfa iç tutarlık katsayısı 0,86 olarak bildirilmiştir. ${ }^{20} \mathrm{Bu}$ araştırmada BUÖ’nün cronbach alfa katsayısı 0,27 olarak bulunmuştur.
Verilerin Analizi: Verilerin analizinde SPSS programından yararlanılmıştır. Verilerin değerlendirilmesinde sayılarla yüzdelik dağılımlar, Ki-Kare analizi kullanılmıştır. Çapraz tablolardaki denek sayılarının yetersiz olduğu durumlarda Montecarlo-Similasyon tekniği ile Ki-Kare analizi uygulanmıştır. Anlamlılık seviyesi olarak $\mathrm{p}<0,05$ belirlenmiştir.

\section{BULGULAR}

Çalışmanın sosyo-demografik verileri incelendiğinde; hemşirelerin \%80,5'inin kadın, \%41,5'inin 36-45 yaş aralığında, \%65'inin kliniklerde çalıştığı, \% 79,7'sinin evli, \%52'sinin ikiden fazla çocuğa sahip olduğu, \%56,1'inin ön lisans eğitim düzeyinde olduğu, \%57,7'sinin 16 y1l ve üzerinde çalışmakta olduğu, \%56,1'inin gündüz+nöbet şeklinde çalıştığı, \% 63,4'ünün gelirini giderinden fazla algıladığı ve \% 42,3'ünün de kişiler arası ilişkilerini iyi olarak alg1ladığı görülmektedir (Tablo 1).

Araştırmada hemşireler; YDÖ'den 5-35, BUÖ'den ise 0-19 arası puan almıştır. Hemşirelerin YDÖ ve BUÖ toplam puan ortalamaları sırasıyla 10,30 $\pm 7,03$

Tablo 1. Hemşirelerin tanımlayıcı özellikleri ( $\mathrm{N}=123)$.

\begin{tabular}{|c|c|c|c|}
\hline \multicolumn{2}{|l|}{ Değișkenler } & \multirow{2}{*}{$\begin{array}{c}\mathbf{n} \\
99\end{array}$} & \multirow{2}{*}{$\begin{array}{c}\% \\
80,5\end{array}$} \\
\hline & Kadın & & \\
\hline Cinsiyet & Erkek & 24 & 19,5 \\
\hline \multirow{4}{*}{ Yaş } & 25 ve $\downarrow$ & 15 & 12,2 \\
\hline & $26-35$ & 26 & 21,1 \\
\hline & $36-45$ & 51 & 41,5 \\
\hline & $45 \mathrm{ve} \uparrow$ & 31 & 25,2 \\
\hline \multirow{4}{*}{ Çalışılan birim } & Klinik & 80 & 65 \\
\hline & Poliklinik & 8 & 6,5 \\
\hline & Acil servis & 12 & 9,8 \\
\hline & Yoğun bakım & 23 & 18,7 \\
\hline \multirow{3}{*}{ Medeni durum } & Evli & 98 & 79,7 \\
\hline & Bekar & 22 & 17,9 \\
\hline & Dul/boşanmış & 3 & 2,4 \\
\hline \multirow{3}{*}{ Çocuk sayısı } & Yok & 27 & 22 \\
\hline & 1 & 32 & 26 \\
\hline & $2 \mathrm{ve} \uparrow$ & 64 & 52 \\
\hline \multirow{4}{*}{ Eğitim durumu } & Sağlık meslek lisesi & 15 & 12,2 \\
\hline & Ön lisans & 69 & 56,1 \\
\hline & Lisans & 34 & 27,6 \\
\hline & Lisansüstü & 5 & 4,1 \\
\hline \multirow{4}{*}{ Çalışma yılı } & 5 y1l ve $\downarrow$ & 21 & 17,1 \\
\hline & $6-10$ y1l & 22 & 17,9 \\
\hline & $11-15 \mathrm{y} 1 \mathrm{l}$ & 9 & 7,3 \\
\hline & $16 \mathrm{yll}$ ve $\uparrow$ & 71 & 57,7 \\
\hline \multirow{3}{*}{ Çalışma şekli } & Gündüz & 37 & 30,1 \\
\hline & Nöbet & 17 & 13,8 \\
\hline & Gündüz+nöbet & 69 & 56,1 \\
\hline \multirow{3}{*}{ Gelir durumu } & Gelir giderden az & 78 & 11,4 \\
\hline & Gelir gidere eşit & 31 & 25,2 \\
\hline & Gelir giderden fazla & 14 & 63,4 \\
\hline \multirow{4}{*}{ Kişiler arası ilişkileri algılama durumu } & Çok iyi & 24 & 19,5 \\
\hline & İyi & 52 & 42,3 \\
\hline & Orta & 34 & 27,6 \\
\hline & Kötü & 13 & 10,6 \\
\hline
\end{tabular}


Tablo 2. Hemşirelerin yaşam doyumu ve Beck umutsuzluk puan ortalaması $(\mathrm{N}=123)$

\begin{tabular}{|l|c|c|c|c|c|}
\hline Ölçek & $\mathbf{n}$ & Mean & SD* & Min. & Maks. \\
\cline { 1 - 4 } Yaşam doyumu ölçeği puanları & \multirow{2}{*}{123} & 10,30 & 7,03 & 5 & 35 \\
\cline { 1 - 3 } Beck umutsuzluk ölçeği puanları & & 6,06 & 4,63 & 1 & 19 \\
\hline
\end{tabular}

*: Standart Deviasyon

ve $6,06 \pm 4,63$ 'tür. Ölçeklere ilişkin toplam puan ortalamaları baz alındığında hemşirelerin orta düzeyde yaşam doyumunda ve hafif düzeyde umutsuz oldukları belirlenmiştir (Tablo 2).
Hemşirelerin tanımlayıcı özelliklerine göre YDÖ toplam puan ortalamaları karşılaştırıldığında; orta düzeyde yaşam doyumunda olma durumu erkeklerde kadınlara oranla belirgin derecede yüksek iken, dü-

Tablo 3. Hemşirelerin sosyo-demografik özelliklerine göre yaşam doyumu ölçeği puanlarının incelenmesi $(\mathrm{N}=123)$.

\begin{tabular}{|c|c|c|c|c|c|c|c|c|c|c|c|}
\hline \multirow{3}{*}{\multicolumn{2}{|c|}{ Değişkenler }} & \multicolumn{10}{|c|}{ Yaşam Doyumu Düzeyleri } \\
\hline & & \multicolumn{2}{|c|}{ Düşük } & \multicolumn{2}{|c|}{ Orta } & \multicolumn{2}{|c|}{ Yüksek } & \multicolumn{2}{|c|}{ Total } & \multirow{2}{*}{$\mathbf{X}^{2}$} & \multirow[b]{2}{*}{$\mathbf{p}$} \\
\hline & & $\mathbf{n}$ & $\%$ & $\mathbf{n}$ & $\%$ & $\mathbf{n}$ & $\%$ & $\mathbf{n}$ & $\%$ & & \\
\hline \multirow{2}{*}{ Cinsiyet } & Kadın & 54 & 54,5 & 14 & 14,1 & 31 & 31,3 & 99 & 100,0 & \multirow{2}{*}{12,6} & \multirow{2}{*}{$0,002 *$} \\
\hline & Erkek & 10 & 41,7 & 11 & 45,8 & 3 & 12,5 & 24 & 100,0 & & \\
\hline \multirow{4}{*}{ Yaş } & 25 ve $\downarrow$ & 10 & 66,7 & 2 & 13,3 & 3 & 20,0 & 15 & 100,0 & \multirow{4}{*}{5,8} & \multirow{4}{*}{0,435} \\
\hline & $26-35$ & 10 & 38,5 & 5 & 19,2 & 11 & 42,3 & 26 & 100,0 & & \\
\hline & $36-45$ & 25 & 49,0 & 12 & 23,5 & 14 & 27,5 & 51 & 100,0 & & \\
\hline & $45 \mathrm{ve} \uparrow$ & 19 & 61,3 & 6 & 19,4 & 6 & 19,4 & 31 & 100,0 & & \\
\hline \multirow{4}{*}{ Çalışılan birim } & Klinik & 43 & 53,8 & 18 & 22,5 & 19 & 23,8 & 80 & 100,0 & \multirow{4}{*}{-} & \multirow{4}{*}{0,147} \\
\hline & Poliklinik & 6 & 75,0 & 0 & 0,0 & 2 & 25,0 & 8 & 100,0 & & \\
\hline & Acil & 6 & 50,0 & 4 & 33,3 & 2 & 16,7 & 12 & 100,0 & & \\
\hline & $\begin{array}{l}\text { Yoğun } \\
\text { bakım }\end{array}$ & 9 & 39,1 & 3 & 13,0 & 11 & 47,8 & 23 & 100,0 & & \\
\hline \multirow{3}{*}{ Medeni durum } & Evli & 52 & 53,1 & 19 & 19,4 & 27 & 27,6 & 98 & 100,0 & \multirow{3}{*}{ - } & \multirow{3}{*}{0,824} \\
\hline & Bekar & 10 & 45,5 & 5 & 22,7 & 7 & 31,8 & 22 & 100,0 & & \\
\hline & $\begin{array}{l}\text { Boşanmış/ } \\
\text { Dul }\end{array}$ & 2 & 66,7 & 1 & 33,3 & 0 & 0,0 & 3 & 100,0 & & \\
\hline \multirow{3}{*}{ Çocuk durumu } & Yok & 14 & 51,9 & 6 & 22,2 & 7 & 25,9 & 27 & 100,0 & \multirow{3}{*}{0,334} & \multirow{3}{*}{0,988} \\
\hline & 1 & 16 & 50,0 & 6 & 18,8 & 10 & 31,3 & 32 & 100,0 & & \\
\hline & $2 \mathrm{ve} \uparrow$ & 34 & 53,1 & 13 & 20,3 & 17 & 26,6 & 64 & 100,0 & & \\
\hline \multirow{4}{*}{ Eğitim durumu } & $\begin{array}{l}\text { Sağlık } \\
\text { meslek } \\
\text { lisesi }\end{array}$ & 8 & 53,3 & 3 & 20,0 & 4 & 26,7 & 15 & 100,0 & \multirow{4}{*}{-} & \\
\hline & Ön lisans & 39 & 56,5 & 20 & 29,0 & 10 & 14,5 & 69 & 100,0 & & $0,003 *$ \\
\hline & Lisans & 15 & 44,1 & 2 & 5,9 & 17 & 50,0 & 34 & 100,0 & & \\
\hline & Lisansüstü & 2 & 40,0 & 0 & 0,0 & 3 & 60,0 & 5 & 100,0 & & \\
\hline & 5 y1l ve $\downarrow$ & 11 & 52,4 & 5 & 23,8 & 5 & 23,8 & 21 & 100,0 & & \\
\hline & 6-10 y1l & 10 & 45,5 & 4 & 18,2 & 8 & 36,4 & 22 & 100,0 & & \\
\hline Çalışma yılı & $11-15$ y1l & 2 & 22,2 & 2 & 22,2 & 5 & 55,6 & 9 & 100,0 & - & 0,396 \\
\hline & 16 yil ve $\uparrow$ & 41 & 57,7 & 14 & 19,7 & 16 & 22,5 & 71 & 100,0 & & \\
\hline & Gündüz & 20 & 54,1 & 3 & 8,1 & 14 & 37,8 & 37 & 100,0 & & \\
\hline & Nöbet & 8 & 47,1 & 7 & 41,2 & 2 & 11,8 & 17 & 100,0 & & \\
\hline Çalışma şekli & $\begin{array}{l}\text { Gün- } \\
\text { düz+nöbet }\end{array}$ & 36 & 52,2 & 15 & 21,7 & 18 & 26,1 & 69 & 100,0 & - & $0,048 *$ \\
\hline & $\begin{array}{l}\text { Gelir gider- } \\
\text { den az }\end{array}$ & 37 & 47,4 & 21 & 26,9 & 20 & 25,6 & 78 & 100,0 & & \\
\hline Gelir durumu & $\begin{array}{l}\text { Gelir gide- } \\
\text { re eşit }\end{array}$ & 20 & 64,5 & 2 & 6,5 & 9 & 29,0 & 31 & 100,0 & - & 0,159 \\
\hline & $\begin{array}{l}\text { Gelir gider- } \\
\text { den fazla }\end{array}$ & 7 & 50,0 & 2 & 14,3 & 5 & 35,7 & 14 & 100,0 & & \\
\hline Sosyal yaşamada & Çok iyi & 13 & 54,2 & 5 & 20,8 & 6 & 25,0 & 24 & 100,0 & & \\
\hline kişiler arası & İyi & 29 & 55,8 & 7 & 13,5 & 16 & 30,8 & 52 & 100,0 & & 0.674 \\
\hline ilişkileriniz nasıl- & Orta & 15 & 44,1 & 9 & 26,5 & 10 & 29,4 & 34 & 100,0 & - & $0,0 / 4$ \\
\hline dır? & Kötü & 7 & 53,8 & 4 & 30,8 & 2 & 15,4 & 13 & 100,0 & & \\
\hline
\end{tabular}

$\mathrm{X}^{2}$ : Ki Kare Analizi; *: $\mathrm{P}<0,05$. 
şük ve yüksek düzeyde yaşam doyumu durumu ise kadınlarda erkeklere göre daha yüksektir $(p<0,05)$, (Tablo 3).

Eğitim durumu lisans ve lisansüstü olanlarda orta düzeyde yaşam doyumu oranları daha yüksek görülürken, lise ve ön lisans grubunda ise yaşam doyumu düşük olma durumu daha yüksek görülmektedir $(\mathrm{p}<0,05)$, (Tablo 3). Çalışma şekli yalnızca gündüz olan hemşirelerin yüksek yaşam doyumu oranı diğer gruplara (gündüz+nöbet veya yalnızca nöbet) göre daha yüksektir $(\mathrm{p}<0,05)$, (Tablo 3 ).

Hemşirelerin demografik özelliklerine göre BUÖ toplam puan ortalamaları karşılaştırıldığında; çalışma yılı 11-15 arasında olan ve kişiler arası ilişkilerini orta ve kötü düzeyde algılayanların daha yüksek

Tablo 4. Hemşirelerin sosyo-demografik özelliklerine göre Beck umutsuzluk ölçeği puanlarının incelenmesi.

\begin{tabular}{|c|c|c|c|c|c|c|c|c|c|c|c|c|c|}
\hline \multirow{3}{*}{\multicolumn{2}{|c|}{ Değişkenler }} & \multicolumn{12}{|c|}{ Umutsuzluk Düzeyleri } \\
\hline & & \multicolumn{2}{|c|}{ Normal } & \multicolumn{2}{|c|}{ Hafif } & \multicolumn{2}{|c|}{ Orta } & \multicolumn{2}{|c|}{ Yoğun } & \multicolumn{2}{|c|}{ Total } & \multirow{2}{*}{$\mathbf{X}^{2}$} & \multirow{2}{*}{$\mathbf{p}$} \\
\hline & & $\mathrm{n}$ & $\%$ & $\mathrm{n}$ & $\%$ & $\mathbf{n}$ & $\%$ & $\mathrm{n}$ & $\%$ & $\mathbf{n}$ & $\%$ & & \\
\hline \multirow{2}{*}{ Cinsiyet } & Kadın & 32 & 32,3 & 46 & 46,5 & 10 & 10,1 & 11 & 11,1 & 99 & 100,0 & & \multirow{2}{*}{0,384} \\
\hline & Erkek & 11 & 45,8 & 7 & 29,2 & 4 & 16,7 & 2 & 8,3 & 24 & 100,0 & & \\
\hline \multirow{4}{*}{ Yaş } & 25 ve $\downarrow$ & 8 & 53,3 & 4 & 26,7 & 3 & 20,0 & 0 & 0,0 & 15 & 100,0 & & \multirow{4}{*}{0,431} \\
\hline & $26-35$ & 11 & 42,3 & 9 & 34,6 & 2 & 7,7 & 4 & 15,4 & 26 & 100,0 & & \\
\hline & $36-45$ & 17 & 33,3 & 24 & 47,1 & 5 & 9,8 & 5 & 9,8 & 51 & 100,0 & & \\
\hline & 45 ve $\uparrow$ & 7 & 22,6 & 16 & 51,6 & 4 & 12,9 & 4 & 12,9 & 31 & 100,0 & & \\
\hline \multirow{4}{*}{ Çalışılan birim } & Klinik & 28 & 35,0 & 36 & 45,0 & 9 & 11,3 & 7 & 8,8 & 80 & 100,0 & \multirow{4}{*}{-} & \multirow{4}{*}{0,957} \\
\hline & Poliklinik & 3 & 37,5 & 4 & 50,0 & 1 & 12,5 & 0 & 0,0 & 8 & 100,0 & & \\
\hline & Acil & 4 & 33,3 & 4 & 33,3 & 2 & 16,7 & 2 & 16,7 & 12 & 100,0 & & \\
\hline & Yoğun bakım & 8 & 34,8 & 9 & 39,1 & 2 & 8,7 & 4 & 17,4 & 23 & 100,0 & & \\
\hline \multirow{3}{*}{ Medeni durum } & Evli & 32 & 32,7 & 46 & 46,9 & 11 & 11,2 & 9 & 9,2 & 98 & 100,0 & \multirow{3}{*}{-} & \multirow{3}{*}{0,577} \\
\hline & Bekar & 10 & 45,5 & 6 & 27,3 & 3 & 13,6 & 3 & 13,6 & 22 & 100,0 & & \\
\hline & Boşanmış/Dul & 1 & 33,3 & 1 & 33,3 & 0 & 0,0 & 1 & 33,3 & 3 & 100,0 & & \\
\hline \multirow{3}{*}{ Çocuk durumu } & Yok & 11 & 40,7 & 9 & 33,3 & 4 & 14,8 & 3 & 11,1 & 27 & 100,0 & \multirow{3}{*}{-} & \multirow{3}{*}{0,716} \\
\hline & 1 & 14 & 43,8 & 12 & 37,5 & 3 & 9,4 & 3 & 9,4 & 32 & 100,0 & & \\
\hline & $2 \mathrm{ve} \uparrow$ & 18 & 28,1 & 32 & 50,0 & 7 & 10,9 & 7 & 10,9 & 64 & 100,0 & & \\
\hline \multirow{4}{*}{ Eğitim durumu } & Sağlık Meslek Lisesi & 6 & 40,0 & 9 & 60,0 & 0 & 0,0 & 0 & 0,0 & 15 & 100,0 & & \multirow{4}{*}{0,051} \\
\hline & Ön lisans & 28 & 40,6 & 28 & 40,6 & 8 & 11,6 & 5 & 7,2 & 69 & 100,0 & _ & \\
\hline & Lisans & 9 & 26,5 & 12 & 35,3 & 5 & 14,7 & 8 & 23,5 & 34 & 100,0 & & \\
\hline & Lisansüstü & 0 & 0,0 & 4 & 80,0 & 1 & 20,0 & 0 & 0,0 & 5 & 100,0 & & \\
\hline & 5 yil ve $\downarrow$ & 12 & 57,1 & 5 & 23,8 & 4 & 19,0 & 0 & 0,0 & 21 & 100,0 & & \\
\hline Calsma & 6-10 y1l & 9 & 40,9 & 9 & 40,9 & 1 & 4,5 & 3 & 13,6 & 22 & 100,0 & & $0000 *$ \\
\hline 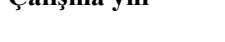 & $11-15 \mathrm{y} 1 \mathrm{l}$ & 1 & 11,1 & 2 & 22,2 & 1 & 11,1 & 5 & 55,6 & 9 & 100,0 & 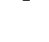 & 0,000 \\
\hline & 16 yıl ve $\uparrow$ & 21 & 29,6 & 37 & 52,1 & 8 & 11,3 & 5 & 7,0 & 71 & 100,0 & & \\
\hline & Gündüz & 16 & 43,2 & 16 & 43,2 & 1 & 2,7 & 4 & 10,8 & 37 & 100,0 & & \\
\hline Çalışma şekli & Nöbet & 6 & 35,3 & 6 & 35,3 & 4 & 23,5 & 1 & 5,9 & 17 & 100,0 & - & 0,357 \\
\hline & Gündüz+nöbet & 21 & 30,4 & 31 & 44,9 & 9 & 13,0 & 8 & 11,6 & 69 & 100,0 & & \\
\hline & Gelir giderden az & 26 & 33,3 & 30 & 38,5 & 11 & 14,1 & 11 & 14,1 & 78 & 100,0 & & \\
\hline Gelir durumu & Gelir gidere eşit & 10 & 32,3 & 17 & 54,8 & 2 & 6,5 & 2 & 6,5 & 31 & 100,0 & - & 0,353 \\
\hline & Gelir giderden fazla & 7 & 50,0 & 6 & 42,9 & 1 & 7,1 & 0 & 0,0 & 14 & 100,0 & & \\
\hline & Çok iyi & 16 & 66,7 & 8 & 33,3 & 0 & 0,0 & 0 & 0,0 & 24 & 100,0 & & \\
\hline $\begin{array}{l}\text { Sosyan yaşamoa } \\
\text { kișiler arası }\end{array}$ & İyi & 12 & 23,1 & 27 & 51,9 & 9 & 17,3 & 4 & 7,7 & 52 & 100,0 & & $0004 * *$ \\
\hline ilişkileriniz nasıl- & Orta & 10 & 29,4 & 12 & 35,3 & 5 & 14,7 & 7 & 20,6 & 34 & 100,0 & & $0,004 \cdots$ \\
\hline & Kötü & 5 & 38,5 & 6 & 46,2 & 0 & 0,0 & 2 & 15,4 & 13 & 100,0 & & \\
\hline
\end{tabular}


Tablo 5. Hemşirelerin yaşam doyumları ile umutsuzluk düzeyleri arasındaki ilişki (N=123).

\begin{tabular}{|c|c|c|c|c|c|c|c|c|c|c|c|}
\hline \multirow{2}{*}{\multicolumn{2}{|c|}{ Ölçek }} & \multicolumn{10}{|c|}{ Yașam Doyumu } \\
\hline & & \multicolumn{2}{|c|}{ Düşük } & \multicolumn{2}{|c|}{ Orta } & \multicolumn{2}{|c|}{ Yüksek } & \multicolumn{2}{|c|}{ Total } & \multirow{2}{*}{$\mathrm{X}^{2}$} & \multirow[b]{2}{*}{ p } \\
\hline & & $\mathbf{n}$ & $\%$ & $\mathbf{n}$ & $\%$ & $\mathbf{n}$ & $\%$ & n & $\%$ & & \\
\hline \multirow{5}{*}{ Beck Umutsuzluk } & Normal & 22 & 51,2 & 14 & 32,6 & 7 & 16,3 & 43 & 100,0 & \multirow{5}{*}{ - } & \multirow{5}{*}{$0,002 *$} \\
\hline & Hafif & 30 & 56,6 & 5 & 9,4 & 18 & 34,0 & 53 & 100,0 & & \\
\hline & Orta & 9 & 64,3 & 4 & 28,6 & 1 & 7,1 & 14 & 100,0 & & \\
\hline & Yoğun & 3 & 23,1 & 2 & 15,4 & 8 & 61,5 & 13 & 100,0 & & \\
\hline & Total & 64 & 52,0 & 25 & 20,3 & 34 & 27,6 & 123 & 100,0 & & \\
\hline
\end{tabular}

$\mathrm{X}^{2}=$ Ki Kare Analizi; *: $\mathrm{P}<0,05$

oranda yoğun umutsuz olduğu ortaya konmuştur $(\mathrm{p}<0,05)$, (Tablo 4).

YDÖ ve BUÖ toplam puan ortalamaları ilişkisi değerlendirildiğinde; yoğun derecede umutsuz olan hemşirelerin, yaşam doyumlarının yüksek oranda ( $\%$ $61,5)$ olduğu belirlenmiştir $(\mathrm{p}<0,05)$, (Tablo 5).

\section{TARTIŞMA VE SONUÇ}

Literatürde yaşam doyumu ve umutsuzluk düzeyi arasındaki ilişkiyi inceleyen birçok çalışma bulunmaktadır. ${ }^{1,21}$ Ancak hemşirelerin yaşam doyumu ve umutsuzluk düzeylerini değerlendiren çalışmaya rastlanılmamıştır. Buradan hareketle tartışma bölümünde çeşitli meslek ve örneklem gruplarına ait çalışmalardan faydalanılmıştır. Çalışmada hemşireler orta düzeyde yaşam doyumuna sahiptir. Tunceli'de 2017 yılında 174 hemşire ile gerçekleştirilen çalışma ile 2018 y1lında Polonya'da 756 hemşire ile gerçekleştirilen çalışmalarda da bu çalışma ile benzer olarak hemşirelerin orta düzeyde yaşam doyumuna sahip oldukları ortaya konmuştur. ${ }^{8,9}$ Ayrıca bazı çalışmalarda da hemşirelerin yüksek düzeyde bir yaşam doyumuna sahip oldukları bildirilmiştir. ${ }^{10}$ Bu farklılıkların, çeşitli çalışmalarda yer alan hemşirelerin sosyo-demografik özelliklerinin değişkenlik göstermesinden kaynaklandığı düşünülmektedir.

Çalışmada hemşirelerin hafif düzeyde umutsuz oldukları saptanmıştır. Farklı örneklem gruplarıyla gerçekleştirilen çeşitli çalışmalarda bireylerin orta düzeyde umutsuzluk yaşadıkları ortaya konmuştur. ${ }^{22}$ Türkiye'de 2020 yılında aktif çalışan 2156 (\%52'si hemşire ve diğer sağlık profesyoneli) bireyle gerçekleştirilen bir çalışmada; hemşirelerin umutsuzluk düzeylerinin hekimlerden daha yüksek olduğu ifade edilmektedir. $^{23}$ Bir diğer çalışma ise İstanbul'da 2019 yılında kamu ve özel kuruluşlarda görev yapan 405 katılımcı (yaklaşık \%50'si hemşire) ile gerçekleştirilmiş; bankacı, akademisyen gibi meslek gruplarına oranla hemşirelerin daha yoğun düzeyde umutsuzluk yaşadıkları belirlenmiştir. Ayrıca ölüm vakalarıyla sık karşılaşan hemşirelerin umutsuzluk düzeyinin daha da arttığı vurgulanmıştır. ${ }^{24} \mathrm{Bu}$ çalış- mada farklı bir bulgu ortaya konması, araştırmanın örneklemini oluşturan hemşirelerin çoğunluğunun (\%65) yoğun bakım dişı servislerde çalışmasıyla açıklanabilir. Hemşirelerin diğer sağlık personeli ve toplum kesimlerine oranla daha yoğun umutsuzluk yaşıyor olmaları; hasta bireyler ve yakınlarıyla daha uzun süreli iletişim kurmaları, yoğun çalışma saatleri, uyku durumlarının bu kapsamda olumsuz etkilenmesi ve yorucu işleri ile açıklanabilir.

Araştırmada kadın hemşirelerin erkeklere oranla daha yüksek yaşam doyumuna sahip olduğu belirlenmiştir. Bu çalışmaya benzer bir şekilde 2019 y1lında Edirne ve İstanbul'da Özel Eğitim ve Rehabilitasyon Merkez'lerinde çalışan 175 öğretmen ile gerçekleştirilen çalışmada da kadınların daha yüksek yaşam doyumunda olduğu saptanmıştır. ${ }^{25}$ Ancak cinsiyet farkının anlamsız olduğunun bildirildiği çalışmalar da mevcuttur. ${ }^{8,13} \mathrm{Bu}$ araştırmada yaşam doyumu ve cinsiyet değişkeni arasında anlamlı bir ilişkinin var olması kadınların dünyaya daha pozitif bakmaları ile açıklanabilir. Türkiye'de kadınlarda yaşamdan ve işten beklentilerin erkeklere göre daha farklı olduğu ifade edilmektedir. Ataerkil bir toplum olmamızdan hareketle Türkiye'de kadınlar daha çok ev ve çocukla ilgili görev ve sorumlulukları önemli ölçüde alırken, erkekler daha çok ev dışındaki görev ve sorumlukları almaktadır. Kadınlar buna rağmen çoğunlukla ikincil statüde görülmektedir. ${ }^{12}$ Ekonomik özgürlüğünü elinde bulundurarak iş ve üretim hizmetlerinde görev alan kadınlar sosyal konumlarını güçlendirebilmektedir. İş hayatına atılınılmasıyla birlikte geleneksel kadın kimliği değişerek, kadınların işe verdiği değerin artmasıyla iş doyumlarını da artırmaktadır. İş doyumunun artması yaşam doyumunun artmasını da beraberinde getirmektedir. ${ }^{12}$

Araştırmada eğitim düzeyi yükseldikçe yaşam doyumunun arttığ1 ortaya konmuştur. Lise ve ön lisans eğitim düzeyine sahip bireyler daha çok düşük yaşam doyumuna sahipken, lisans ve lisansüstü düzeyde eğitim seviyesinde olan hemşirelerin ise daha çok orta düzeyde yaşam doyumuna sahip oldukları ortaya konmuştur. Litaretürde bu bulguları destekleyen 
birçok çalışmaya ulaşılmıştır. ${ }^{3,26} \mathrm{Bu}$ araştırmaların sonuçları değerlendirildiğinde; lisansüstü eğitime sahip hemşirelerin kendi eğitim seviye ve becerilerine uygun görev ve sorumluklar almış olabileceği düşünülebilir. Hemşirelerde artan eğitim seviyesi; etkin stresle baş etme, artmış sorun çözme becerisi, tükenmişlikle baş etme, profesyonelleşme ve problem çözme becerisini geliştirmeyle paraleldir. Bu faktörler, hemşirelerde eğitim seviyesinin artmasının yaşam doyumuna olumlu etkisine işaret etmektedir. ${ }^{26}$ Norveç'te 2007-2008 yılları arasında 4192 bireyin $(478$ 'i hemşire- \%11,4) yaşam kalitelerinin değerlendirildiği bir çalışmada da bu araştırmaya benzer sonuçlara ulaşılmış, eğitim düzeyi ve yaşam doyumu arasında anlamlı bir ilişki bulunmuş ve eğitim düzeyi yükseldikçe, iş doyumunun artacağı ve yaşam doyumunun da buna paralel olarak yükseleceği ifade edilmiştir. ${ }^{11}$ Malatya'da 2014-2015 y1lları arasında 65 yaş üzeri 320 kişi ile gerçekleştirilen bir diğer çalışmada da benzer sonuçlara ulaşılmış ve yüksekokul mezunu yaşlı bireylerin, okuryazar olmayan yaşlı bireylere oranla daha yüksek yaşam doyumunda oldukları belirtilmiştir. ${ }^{13}$ Eğitim seviyesinin yükselmesi artmış gelir seviyesinin göstergesidir. Artmış gelir seviyesinde bireylerin geçim kaygıs1 gibi sorumluluklarını yerine getirme durumuna ilişkin endişeleri daha az olmaktadır. ${ }^{11}$ Bu sebeple artmış gelir düzeyine sahip bireylerin daha yüksek yaşam doyumuna sahip olması beklenmektedir. Çalışma bu yönden literatür ile uyumludur.

Yalnızca gündüz çalışan hemşirelerin yaşam doyumlarının gündüz ve nöbet, yalnızca nöbet sistemi şeklinde çalışanlara göre daha yüksek yaşam doyumunda oldukları belirlenmiştir. Çalışma sonuçlarına paralel olarak bir diğer çalışmada da Polonya'da 2019 yılında 70 onkoloji hemşiresinin yaşam doyumları incelenmiş ve sürekli gündüz mesaisinde olan hemşirelerin, gündüz ve gece nöbeti şeklinde çalışanlara göre daha yüksek yaşam doyumunda oldukları saptanmıştır. ${ }^{3}$ Manisa Soma Devlet Hastanesi'nde 2013 -2014 yılları arasında 142 sağlık personeli (\%50,7'si hemşire) ile yürütülen benzer bulgulara sahip bir diğer çalışmada ise; iş yükünün yeterli düzeyde olduğunu düşünenlerle yalnızca gündüz mesaisi şeklinde çalışanların yaşam doyumlarının daha yüksek düzeyde olduğu bildirilmiştir. Aynı çalışmada iş yükünün fazla olmadığını düşünme ve işten memmun olmanın yüksek yaşam doyumunu etkileyen faktörler olduğu vurgulanmıştır. ${ }^{27}$ Çalışma şekli düşünüldüğünde devamlı gündüz çalışan hemşirelerin daha düzenli bir yaşam şekline sahip olmaları, gece-gündüz nöbetli sistemde çalışanların ise sosyal yaşam düzensizliği, hemşirelerin ailelerine olan görev ve sorumluluklarının olumsuz etkilenmesi ile bunların yerine getirilememesine ve nöbet ertesi dinleme zaman aralıklarının, süreklilik gösteren sorumlulukları sebebiyle daha dar olması bu iki grup arasındaki yaşam doyumu farkını açıklayabilir. Tüm bu nedenler gece-gündüz nöbetli sistemde çalışan hemşirelerin daha düşük yaşam doyumunda olmasını desteklemektedir. Hemşirelerin daha düşük yaşam doyumunda olması vermiş oldukları bakımın kalitesine de yansıyacağı için hasta bireyler tarafindan verilen geri bildirimler de bu kapsamda olumsuz bir hal alacak ve hemşirelerde yaşam doyumunun daha da düşük olmasına yol açacaktır.

Çalışma yılı 11-15 yıl arasında olan ve kişiler arası ilişkilerini orta ve kötü düzeyde algılayan hemşirelerin diğerlerine göre daha yoğun umutsuzluk yaşadıkları belirlenmiştir. Batman Devlet Hastanesi'nde 2019 yılında 75 yoğun bakım hemşiresi ile yürütülen bir çalışmada; çalışma süresi daha az olan hemşirelerin umutsuzluk düzeylerinin daha yüksek olduğu bildirilmektedir. ${ }^{28} \mathrm{Bu}$ durumun mesleğine yeni başlayan hemşirelerin çoğunlukla yoğun bakım ünitelerinde görevlendirilmeleri ile iş yaşamına ilişkin beklentilerinin karşılanamamış olmasından kaynaklanabileceği düşünülmektedir. Türkiye'de bir şehir hastanesinde 261 hemşire ile 2020 yılında yürütülen bir diğer çalışmada ise hemşirelerin meslekte çalışma y1lı ile umutsuzluk düzeyleri arasında anlamlı bir ilişki olmadığı bildirilmektedir. ${ }^{29}$ Konuya ilişkin olarak 2014 yılında Muğla Sağlık Yüksekokulu Hemşirelik Bölümü 3. ve 4. sınıf 270 öğrenci ile yapılan benzer bir diğer çalışmada da özellikle okulda arkadaşları ile sosyal ilişkilerini yetersiz olarak değerlendiren öğrencilerin daha yoğun düzeyde umutsuzluk yaşadıkları belirlenmiştir. ${ }^{30}$ Sosyal ilişkileri iyi olmayan bireyler kendilerini daha çok yalnızlığa itmektedir. Bireyler tek başlarına kaldıklarında yalnızlıkla baş etme düzeyleri düşebilmekte ve baş etmede yetersizlik de kısır döngü halini alarak umutsuzluğa yol açabilmektedir.

Hemşirelik vardiya sistemi çalışma ile yoğun çalışma saatleri sebebiyle bireyleri kısa sürede yıpratabilmektedir. Bu durum bireylerin iş yaşamı dışındaki sosyal hayatını yönlendirmekte ve yaşam doyumlarının etkilenmesine sebep olabilmektedir. Bu çalışmada araştırma öncesi yaşam doyumu ile umutsuzluk düzeyleri arasındaki ilişkinin negatif yönde ilerleyeceği beklenmiştir. Ancak araştırma sonucu bu beklentiyi değiştirmiş ve yoğun derecede umutsuz olan hemşirelerin, yaşam doyumlarının yüksek oranda (\% $61,5)$ olduğu belirlenmiş̧tir $(p<0,05)$. Balıkesir'de 
2016 y1lında 292 emekli astsubayla yürütülen benzer bir diğer çalışmada ise yoğun düzeyde umutsuzluk deneyimleyen emekli astsubayların \%78,7'sinin düşük düzeyde yaşam doyumuna sahip olduğu tespit edilmiştir. ${ }^{1}$ Erzincan Üniversitesi Mengücek Gazi Eğitim ve Araştırma Hastanesi İç Hastalıkları Kliniği'nde 2012-2013 y1lları arasında 200 kalp hastası ile gerçekleştirilen benzer bir diğer çalışmada ise orta düzeyin üzerinde umutsuz olan hastaların yaşam doyumlarının düşük düzeyde olduğu ifade edilmiş ve böylelikle yaşam doyumu ile umutsuzluk düzeyleri arasında negatif yönde bir ilişki bulunduğu ortaya konmuştur. ${ }^{22} \mathrm{Bu}$ çalışmada yaşam doyumu ve umutsuzluk düzeylerinin paralel yönde ilişkili olması; hemşirelerin daha sosyal davranması, kişiler arası ilişkilerinin daha kuvvetli ve iyi olması, özellikle ilgi alanlarına yönelik olarak hobilerine daha fazla vakit ayırabilmeleri ve umutsuzluk içerisinde olsalar dahi yaşama olumlu, iyimser bakabilmeleri ile açıklanabilir. Yaşama karşı olumlu ve iyimser bakış, yüksek yaşam doyumuyla ilişkili bulunmuştur. ${ }^{21}$ Ek olarak literatürde kadınların yaşam doyumlarının daha yüksek olduğu bildirilmektedir. ${ }^{25} \mathrm{Bu}$ araştırmada yoğun düzeyde umutsuzluk yaşayan hemşirelerde, yüksek düzeyde yaşam doyumuna sahip olunmasının; çalışmanın \%80,5'inin kadınlardan oluşması, katılımcıların \%88,6'sının gelir probleminin olmaması ve \% 61,8 'inin ise kişiler arası ilişkilerini iyi/çok iyi olarak algılamasıyla ilişkili olabileceği düşünülmektedir.

Bu kapsamda;

- Hemşirelerin, yaşam doyumlarının arttırılması için iş yaşamı dışında birbirleri ile daha fazla sosyal aktivitelere katılımları teşvik edilmeli,

- Hemşirelerin yoğun ve zorlu çalışma temposuna bağlı olarak yaşadıkları umutsuzluk düzeylerinin azaltılması için; çalışma süreleri düzenlenmeli, bu amaçla gerekli politikalar oluşturulmalı, hemşireler ilgili kamu kurum ve kuruluşlarına seslerini duyurmalı,

- Mesleki örgütlerle işbirliği içerisinde olunmalı, yaşam doyumunun yükseltilmesi ve umutsuzluk düzeylerinin azaltılması amacıyla sertifikasyon programları, uzaktan veya örgün öğretimle lisans tamamlama gibi uygulamalarla hemşirelerin eğitim seviyelerinin yükseltilmesi önerilebilir.

Etik Komite Onayı: Helsinki Deklarasyonu Prensipleri'ne uygun davranılarak; çalışmanın uygulanmasından önce Amasya Üniversitesinin Girişimsel Olmayan Klinik Araştırmalar Etik kurulundan (Tarih: 22.06.2018, karar no: E.15363) ve Amasya İl Sağlık
Müdürlüğü’nden (Tarih: 08.06.2018, karar no: 91734550-044) yazılı izin alınmıştır.

Çıkar Çatışması: Yazarlar çıkar çatışması bildirmemişlerdir.

Yazar Katkıları: Fikir-İT; Denetleme- İT; Malzemeler- İT; Veri toplanması ve/veya işlemesi-İT; Analiz ve/veya yorum-İT; Yazıyı yazan-İT.

Hakem Değerlendirmesi: Dış bağımsız.

Teşekkür: Araştırmaya katılarak destek olan Amasya Üniversitesi Sabuncuoğlu Şerefeddin Eğitim ve Araştırma Hastanesi hemşirelerine çok teşekkür ederim.

Diğer Bilgi: $\mathrm{Bu}$ araştırma, 26-30 Kasım 2019 tarihlerinde Antalya'da düzenlenen 3. Uluslararası \& 21. Ulusal Halk Sağlığı Kongresi’nde poster bildiri olarak sunulmuştur.

\section{KAYNAKLAR}

1. Küçükoğlu Yalçın L, Özmen D. Emekli astsubayların yaşam doyumu ve umutsuzluk düzeyleri ilişkisi ve etkileyen faktörler. Ege Üniversitesi Hemşirelik Fakültesi Dergisi. 2019;35(3):93-102.

2. Özer M, Karabulut ÖÖ. Yaşlılarda yaşam doyumu. Turk Geriatri Derg. 2003;6(2):72-74.

3. Piotrkowska R, Jarzynkowski P, Książek J, Mędrzycka-Dąbrowska W. Satisfaction with life of oncology nurses in Poland. Int Nurs Rev. 2019;66(3):374-380. doi:10.1111/inr.12521

4. Carpenito LJ. Hemşirelik Tanıları: El Kitabı. 13. baskı. İstanbul: Nobel Tip Kitabevleri; 2012.

5. Park EY, Choi YI, Kim JH. Psychometric properties of the Korean dispositional hope scale using the rasch analysis in stroke patients. Occup Ther Int. 2019. doi:10.1155/2019/7058415

6. Rueda-Jaimes GE, Castro-Rueda VA, RangelMartinez-Villalba AM, Moreno-Quijano C, Martinez-Salazar GA, Camacho PA. Validation of the Beck Hopelessness Scale in patients with suicide risk. Rev Psiquiatr Salud Ment (Engl Ed). 2018;11(2):86-93.

doi:10.1016/ j.rpsmen.2016.09.004

7. Karakuş H. Hemşirelerin iş tatmin düzeyleri: Sivas ili örneği. Dicle Üniversitesi Sosyal Bilimler Enstitüsü Dergisi (DÜSBED). 2011;3(6):46-57.

8. Benli SS, Yıldırım A. Hemşirelerde yaşam doyumu ve ölüme karşı tutum arasındaki ilişki. Gümüşhane Üniversitesi Sağl1k Bilimleri Dergisi. 2017;6(4):167-179.

9. Marć M, Bartosiewicz A, Burzyńska J, Binkowska-Bury M, Januszewicz P. The quality of life and readiness of Polish nurses to take new competences of drug prescribing. Medicine (Baltimore). 2018;97(36). doi:10.1097/ 


\section{MD.0000000000012129}

10. Abbasi M, Zakerian A, Mehri A, ve ark. Investigation into effects of work-related quality of life and some related factors on cognitive failures among nurses. Int J Occup Saf Ergon. 2017;23(3):386-392. doi:10.1080/10803548.2016.1216991

11. Andresen IH, Hansen T, Grov EK. Norwegian nurses' quality of life, job satisfaction, as well as intention to change jobs. Nord J Nurs Res. 2017;37(2):90-99. doi:10.1177/2057158516676429

12. Uslan UY. Public employees job satisfaction, life satisfaction and burnout levels'assessment by some socia-demographic factors. Journal of Human Sciences. 2016;13(2):3354-3372. doi:10.14687/jhs.v13i2.3983

13. Erci B, Yılmaz D, Budak F. Yaşlı bireylerde özbakım gücü ve yaşam doyumunun umut düzeylerine etkisi. J Psychatric Nurs. 2017;8(2):7276. doi:10.14744/phd.2017.52714

14. Marilaf Caro M, San-Martín M, Delgado-Bolton R, Vivanco L. Empathy, loneliness, burnout, and life satisfaction in Chilean nurses of palliative care and homecare services. Enferm Clin. 2017;27(6):379-386. doi:10.1016/ j.enfcli.2017.04.007

15. Una Cidon E, Cuadrillero Martin F, Hijas Villaizan M, Lopez Lara F. A pilot study of satisfaction in oncology nursing care: An indirect predictor of quality of care. Int J Health Care Qual Assur. 2012;25:106-117. doi:10.1108/09526861211198272

16. Diener E, Emmons RA, Larsen RJ, Griffin S. The satisfaction with life scale. J Pers Assess. 1985;49(1):71-75. doi:10.1207/ s15327752jpa4901_13

17. Dağlı A, Baysal $\bar{N}$. Yaşam doyumu ölçeğinin Türkçe'ye uyarlanması: Geçerlik ve güvenirlik çalışması. Elektronik Sosyal Bilimler Dergisi. 2016;15(59):1250-1262. doi:10.17755/ esosder.263229

18. Softa H, Karaahmetoğlu G, Erdoğan O, Yavuz S. Yaşlılarda yaşam doyumunu etkileyen bazı faktörlerin incelenmesi. Yaşlı Sorunları Araştırma Dergisi (YSAD). 2015;(1):12-21.

19. Beck AT, Weissman A, Lester D, Trexler L. The measurement of pessimism: The hopelessness scale. J Consult Clin Psychol. 1974;42(6):861865. doi:10.1037/h0037562

20. Seber G. Beck umutsuzluk ölçeğinin geçerlik ve güvenirliği üzerine bir çalışma. Anadolu Üniver- sitesi Tıp Fakültesi Psikiyatri Anabilim Dalı, Yayınlanmamış Doçentlik Tezi. Eskişehir, Türkiye. 1991.

21. Shek DT, Li X. Perceived school performance, life satisfaction, and hopelessness: A 4-year longitudinal study of adolescents in Hong Kong. Soc Indic Res. 2016;126(2):921-934. doi:10.1007/s11205-015-0904-y

22. Karakurt P, Aşılar RH, Yıldırım A, Memiş Ş. Determination of hopelessness and quality of life in patients with heart disease: An example from Eastern Turkey. J Relig Health. 2018;57(6):2092 -2107. doi:10.1007/s10943-017-0456-3

23. Hacimusalar Y, Kahve AC, Yasar AB, Aydin MS. Anxiety and hopelessness levels in COVID19 pandemic: A comparative study of healthcare professionals and other community sample in Turkey. J Psychiatr Res. 2020;129:181-188. doi:10.1016/j.jpsychires.2020.07.024

24. Aktürk D, Şahin M. Ölümle çok karşılaşan servislerde çalışan hemşirelerle meslekleri gereği ölümle karşılaşmayan kişilerde ölüm kaygısı, sürekli kayg1 ve umutsuzluk düzeylerinin karş1laştırılması. Avrasya Sosyal ve Ekonomi Araştırmalar1 Dergisi. 2019;6(7):9-23.

25. Yavuz M. Özel eğitim ve rehabilitasyon merkezlerinde çalışan öğretmenlerin mesleki tükenmişlik düzeyleri ve yaşam doyumlarının incelenmesi. OPUS Uluslararası Toplum Araştırmaları Dergisi. 2019;13(19):527-556. doi:10.26466/ opus. 601008

26. Camci G, Kavuran E. Hemşirelerin iş stresi ve tükenmişlik düzeyleri ile meslek ve yaşam doyumu düzeyleri arasındaki ilişkinin belirlenmesi. Anadolu Hemşirelik ve Sağlık Bilimleri Dergisi. 2021;24(2):274-283. doi:10.17049/ ataunihem. 930846

27. Tekir Ö, Çevik C, Arık S, Ceylan G. Sağlık çalışanlarında tükenmişlik, iş doyumu düzeyleri ve yaşam doyumunun incelenmesi. Kırıkkale Üniversitesi Tıp Fakültesi Dergisi. 2016;18(2):51-63. doi:10.24938/kutfd.252677

28. Yeşilçınar İ, Yanık D, Şahin E, Tarhan R. Yoğun bakım hemşirelerinde ahlaki duyarlılık, iş motivasyonu ve umutsuzluk arasındaki ilişkinin belirlenmesi. Journal of Contemporary Medicine. 2019;10 (4):578-584. doi:10.16899/jcm.706285

29. Kayaoğlu K, Polat H, Asi Karakaş S, Şahin Altun Ö. COVID-19 enfeksiyonunun hemşirelerin kayg1 ve umutsuzluk düzeylerine etkisi. Türkiye Klinikleri Hemşirelik Bilimleri Dergisi. 2020. doi:10.5336/nurses.2020-80790 
30. Taslak S, Işıkay Ç. Hemşirelik bölümü öğrencilerinin eğitim algıları ile kaygı ve umutsuzluk düzeylerine yönelik bir araştırma: Sağlık yüksekokulu örneği. Süleyman Demirel Üniversitesi Sağlık Bilimleri Enstitüsü Dergisi. 2015;6(3):108 -115 . 